\title{
Institutional quality and private sector participation: theory and empirical findings
}

Rahel Schomaker, Cologne Business School and German Research Institute for Public Administration Speyer

\begin{abstract}
Through several conduits, sound institutional quality is pivotal for economic development, as there is evidence that stable democratic institutions, rule of law and sound governance structures in the administration are highly conducive to promote growth. Therefore, a high institutional quality is not only the end point, but also the starting point of a more sustainable development. In this paper we provide some theoretical considerations as well as empirical evidence, based on several regression analyses, that the quality of institutions in a wider sense, and governance, which includes not only the level of "politics" itself, but also the administrative level, is relevant not only for the macro-level of development (i.e. the increase of the national welfare and foreign investment), but also on a micro-level: A stronger participation of private enterprises in public service provision and the introduction of public-private partnerships depends to a high degree on the institutional quality. This is even more relevant as the improvement of public services and of core infrastructures can be seen as crucial multipliers for future growth.
\end{abstract}

\section{JEL classification}

A12; A30; P27.

\section{Keywords}

Institutional quality; good governance; institutional economics; public-private partnerships; public goods. 


\section{Introduction}

In several ways, institutional quality is pivotal for economic development. There is much evidence that democratic institutions, the absence of corruption, rule of law, and sound governance structures in the country's administration are conducive to promoting growth in terms of Gross Domestic Product (GDP), or to attracting foreign direct investment (FDI), to mention just some of its most relevant determinants (see for the discussion of the role of institutions e.g. Acemoglu and Robinson, 2012). Democratic governance and accountability are not the end point after a country has undergone economic and social development, but rather the start point of a more sustainable development.

In our paper, we provide some theoretical insights as well as empirical evidence that the quality of institutions, which includes not only the level of "political institutions" itself, but also the administrative level, is relevant not only for achieving the standard macro-level development objectives (e.g. the increase of GDP and FDI). Also on the micro-level - the provision of infrastructure and other public services - institutions matter. In other words, a stronger participation of private enterprises in service provision and the introduction of public-private partnerships depend to a high degree on the institutional quality of a country. This is even more relevant as the improvement of public services and of core infrastructures can be seen as a multiplier for further growth, as theoretical considerations and a substantial number of empirical studies have clearly demonstrated. (Efficient) Investment in public services and infrastructure provides positive growth impulses for the overall economy by fostering entrepreneurship, providing necessary infrastructure for businesses or sending signals to foreign investors (for an overview e.g. Hartwig, 2005). Therefore, as conventional wisdom has it, given that private firms may provide much-needed financial resources as well as superior management know-how and technical expertise for infrastructure provision and public services, the stronger inclusion of private enterprises may be one very promising development "tool" (e.g. Grimsey and Lewis, 2005; Ziekow, 2003). The important role of private enterprises can play in the provision of infrastructure and services is in particular given for all countries that face severe budget constraints in the public sector. While this applies generally to less developed countries, industrialised countries in Europe and the US also face increasing public budget restrictions, triggered not least by the financial crisis of 2008/2009.

Therefore, as the general effect of institutions on the overall economic wellbeing of a country or economic growth rates has been subject to scientific research before (e.g. Acemoglu and Robinson, 2012; Obinger, 2001; Wagener, 2004), our contribution to the existing literature is new in two dimensions. By analysing the "micro-level" of development, focusing on private sector participation, for the first time we provide empirical evidence in how far institutional quality influences the involvement of private firms in the provision of public services. Additionally, by tying the link between institutional quality and the nature of private sector participation, we contribute to the ongoing debate in particular on transaction costs related to private sector participation and public-private partnerships.

Our paper is structured as follows: In the next section, we first apply the theory of "new institutional economics" to explain why sound governance, especially the quality of bureaucracy, and not least of regulatory oversight, and of anti-corruption policies, is a crucial factor in fostering a potentially welfare-increasing stronger inclusion of the private sector. Transaction costs are of specific relevance in this context, as it is reasonable to assume higher transaction costs will, ceteris paribus, always increase the price of cooperations and partnerships (assuming that transaction costs are an integral part of the full costs of contract conclusion and contract enforcement) (Hart, 2005). Based on this, we discuss the economics of private sector involvement more detailed, with a specific focus again on the role of transaction costs. 
After setting up the theoretical framework, we will provide some empirical evidence for the role sound institutions play in the context of the establishment of publicprivate partnerships in infrastructure provision, focusing on a view to the world's less developed countries. We will finish our analysis with a brief conclusion of our main findings and some policy recommendations.

\section{Theoretical background: "new institutional economics" and the "economics of private sector participation"}

\section{Key insights from the "new institutional economics"}

The main hypothesis of institutional economics is that institutions strongly influence human behaviour and therefore also have a strong relevance for the growth and development of countries (or lack thereof) (Acemoglu and Robinson, 2012; Obinger, 2001). While an exclusive and universally accepted definition of institutions is still missing, a rather broad consensus has emerged in the literature on what constitutes institutions and what their principal functions and effects are (for a comprehensive overview see Hodgson, 1998 and Williamson, 2000). Following North (1991 and 1992), institutions are interpreted as 'humanly devised constraints that structure political, economic, and social interactions' (North, 1991). They constitute the framework of a society, which to a high degree determines the individuals' activities by providing crucial information and therefore reducing uncertainty (Voigt, 2002). This framework does not only comprise the so-called material institutions, but also all mechanisms that are able to enforce these very institutions (Erlei et al., 2007).

In particular, institutions that determine the rules of the game and shape governance structures are the focus of NIE and the quantitative approaches that are applied in this context. Institutions at these levels are often seen as vital determinants for economic wealth/welfare (or the lack thereof). At the same time it is relatively easy to identify - in a normative, theory-based approach - how these institutions should be structured to reach the overall goal of "economic growth" and the intermediate goal of "good governance" as a necessary precondition for achieving economic wealth/welfare.

The role of institutions is of specific importance in a setting of incomplete information and uncertainty, as is inevitably - due to prohibitive costs of gathering and processing information - the case in every real-world economic system. Incomplete information or asymmetric information between actors, as well as bounded rationality and the - by nature - limited mental capacities of human beings lead to additional costs, the so-called "transaction costs" (e.g. Coase, 1937). Transaction costs relate to each single market and non-market transaction, may it be with regard to goods or services, or, in what constitutes a broader application of this concept, to the definition, transfer and enforcement of property rights (Richter and Furubotn, 1999). These costs arise due to the fact that in order to perform any of these transactions information on potential counterparts has to be obtained, checked for correctness and assessed in terms of counterparty and other forms of economic risks, and that, eventually, contracts have to be negotiated, monitored and, if necessary, enforced or renegotiated. Transaction costs therefore occur both ex ante, i.e. before a contract is created, and ex post, after the contractual arrangements have been finalised.

Effective and generally respected institutions can help to reduce - though they will never completely eliminate - these transaction costs in several ways by providing some crucial information and some kind of security in an overall framework which is unavoidably characterised by uncertainty about future developments in an essentially unpredictable, dynamic, evolutionary world. The greater degree of 
certainty that the contractual partner will heed the contract provisions will, in turn, enhance the incentives (for individuals and enterprises alike) to engage in a contract in the first place because of the much reduced risks of falling into "hidden traps". In other words, the knowledge itself that one is in the legal position to take a case to court or mediation (e.g. in case of the counterparty's real or alleged breach of contract or for unforeseen renegotiations within the contract duration) will tend to discourage each contract party from acting opportunistically or in outright breach of contract, as this will give rise to substantial costs (including loss of reputational capital etc.). A strong legal system which provides for effective sanctions will therefore be substantially conducive to contract compliance. It will, in turn, lower transaction costs for contractual arrangements in the first place, resulting in more transactions occurring, and, ceteris paribus, in the welfare-enhancing productivity gains which can be harnessed through from the widening and deepening of the division of labour. This is primarily due to the beneficial effect of lower individual costs of control which stem from the existence of efficient institutions which at least partly even out the information asymmetry between (potential and actual) contractual partners. To sum up, in this context, a crucial function of (good) institutions is their signaling to act as stand-ins for the contract partner's trustworthiness and reliability.

For efficiently and effectively fulfilling these functions, good institutions can be regarded as a conditio sine qua non for economic development and a sound longrun economic performance of a country (e.g. recently Acemoglu and Robinson, 2012; see also Apolte, 2004; North, 1991; Sachs and Warner, 1997; Wagener, 2004). As Klein and Luu (2003) state, "[a] key to understanding economic development, then, is institutional development". Consequently, within the last few decades, a whole new branch of literature endeavoured not only to provide for the deeper theoretical understanding of the relevance of institutions, but also to seek robust empirical evidence on the impact of the institutional framework for development.

Most of these empirical studies measure the impact of institutional quality on the economic wealth/welfare of a country, commonly measured in terms of Gross National Product (GNP) or Gross Domestic Product (GDP) figures (per head in US\$ and/or based on purchasing power parities), or the rate of change of these indicators, or use different proxies for economic wealth/welfare. "Institutional quality" in these studies is defined in different ways, and not exclusively as the absence of corruption, good regulatory quality, democratic participation and high accountability of the government, political stability, the secure property rights, and/or efficient public administration. To recapitulate here the main results of an meta-assessment of several seminal empirical studies, independent of their respective definition (and the data sets) used, it can be safely concluded that there is substantial evidence for a significant positive correlation between (high) institutional quality and (positive) rates of economic growth and/or wealth. As, for instance, Obinger (2001) is able to show, while the regime-type itself (democracy vs. dictatorship) does not show a significant curvilinear influence, sound institutions - in the sense of the absence of corruption or a high quality level of the administration - have a significant positive effect on economic growth. Furthermore, and often linked to an overall sound institutional framework, there is some evidence that in the long run especially democratic regimes experience a high level of wealth (Acemoglu and Robinson, 2012).

Klein and Luu (2003) do not focus directly on GDP/GNI data, but on productivity trends in a country, and were able to show that differences in technical efficiency in a country sample can be explained by the specific institutional framework.

In our own analysis, focusing not on the macro-, but on the micro-level, we assume that (good) institutions are important for economic growth as they facilitate privatesector investments in infrastructure and the private sectors contributions to public services. Good institutions provide reliable signals for the private sector to invest, 
as contracts can be secured without prohibitively high transaction costs. If the administration works efficiently, is not corrupt, and transparency as well as reliability on existing contracts can be assumed to be given, it is much more likely that private partners will invest in joint projects, which may result in a better supply of public goods and infrastructure, and therewith in the long run higher economic growth. This is even more important as contracts between the public and the private sector in its different forms arise within the context of incomplete information and uncertainty (Parker and Hartley, 2005). These contracts are "necessarily incomplete" (Erlei et al., 2007). Not all future developments and contingencies can be foreseen by the contract parties, let alone fixed by adequate contract provisions - a fact further compounded by the bounded rationality of the prospective partners, which could result in future opportunistic behaviour from either side (Coase, 1937 and Williamson, 1975/1985). Transaction costs are the logical result of this incompleteness and play a pivotal role for the successful or unsuccessful initiation and longer-term implementation of partnerships (Klein et al., 1996). To be more specific, transaction costs in these partnerships include ex ante the costs of the bidding process, negotiations and the establishment as well as ex post costs for re-negotiations and compliance (Dudkin and Välilä, 2005).

Especially for the private partner the reduction of transaction costs may be decisive: A profit-oriented enterprise will invest in public services only if the anticipated profit will at least cover its costs (plus yield a "reasonable" rate of return on its investment). With transaction costs often being a large percentage of the full project costs, excessive transaction costs may render the whole project unprofitable as a result. A decrease of the (anticipated) transaction costs therefore will likely enhance the probability that contracts conducive to development between the public and the private partner will be realised in the first place.

Another important role of institutions in the context of PPPs lies in the signal they send out to (international) development organisations: Many projects related to development-driven investment in public services and infrastructure are assisted by these development agencies financially, technically and/or through management support (Hammami et al., 2006). In detail, the assistance typically takes place in specific technical support and investment loans as well as through guarantees against political risk, currency risk and (partly) credit risk. This assistance - as well as "conventional" development aid - is usually linked to "good governance" in the meaning of existing democratic structures, the adherence to human rights and the rule of law as well as the existence of (effective) anti-corruption measures (Nuscheler, 2005). By having established sound institutions, a necessary precondition is therefore fulfilled for the public partner to gain direct access to additional funding for the project from international donors. Moreover, for the private partner this also increases the likelihood to obtain financial support or specific warranties from development agencies - a fact which seems to be very important due the high risks of a partnership and/or for the enterprise. Political risks like expropriation or civil unrest, substantial exchange rate risks and additional risks of doing business may then be covered by the development agencies' warranties, so the availability (or lack thereof) of some independent outside protection against said risks seems to bear potentially strong influence a private sector company's penchant to engage in a project.

Additionally, the existence of sound institutions can be seen as a proxy for a government's reputation and stability and, as a result, will prove helpful in attracting more private enterprise activity in that country. This is even more important as any incomplete contract - as outlined above - is inevitably linked to high transaction costs, which, however, can be effectively lowered by mutual trust between the potential partners. Every credible signal of a government's trustworthiness will allow more such partnerships to come to fruition. Summarised, "PPPs cannot be found in areas where institutional failure and governance gaps are exceptionally pronounced" (Schäferhoff et al., 2007: 10). 


\section{The economics of private sector involvement in public goods and infrastructure provision}

Due to shrinking tax revenues, or rising governmental expenditures (i.e. for social security), or a combination of both, more and more state and local governments face severe budgetary restraints. Accordingly, there is a global trend for governments trying to improve their fiscal stance, especially on the expenditure side. At the same time, on the grounds of demographic change as well as resulting from economic growth, the pressure on public goods, particularly on existing infrastructures is raising. ${ }^{1}$ The situation is even more exigent in the less developed parts of the world. Still rising rates of urbanisation, high rates of population growth and rising standards of living have for years increased the stress on public services and infrastructure to the point where demand greatly exceeds supply.

Private investment, or as a broader concept, private sector involvement can be assumed to be one potential solution for the problems outlined above. This investment can take place in different guises - as full or in-part privatisation, or as joint projects in the form of public-private partnerships (PPP) between the public administration and private enterprises, especially international companies.

As privatisation may not be the first best solution from an economic theory perspective as far as public goods - i.e. market failure - are concerned or if the privatisation process might result in merely swapping a state-run for a private monopoly, alternative forms of public-private partnerships exist which may ensure adequate control rights for the public sector over the crucial aspects of service provision. Many of these "new" partnership models are still lacking a precise definition (Budäus and Grüb, 2007). Therefore, in this paper, we use the term public-private partnerships for a whole portfolio of different partnership models which range from full ownership by the public sector to material privatisation (Grimsey and Lewis, 2005). The prevalent definitions of PPP typically focus either on the players involved or on procedural aspects of these partnerships. Linder (1999) broadly defines the term PPP as 'rubric for describing cooperative ventures between the state and private business'. Grimsey and Lewis (2005) see PPPs as 'arrangements whereby private parties participate in, or provide support for, the provision of infrastructure, and a PPP project results in a contract for a private entity to deliver public infrastructure-based services'. Ziekow (2003), by contrast, defines PPP more broadly as the junction of rationalities of actors relevant for action, and therewith refers to the, probably, most important factor in the decision whether or not to pursue a PPP: the interest of both partners.

Regardless of the specific form it may take in practice, any PPP-type contractual agreement between a private company and the public sector - whether at the state or at the municipal level - is typically characterised by a risk-sharing arrangement with the private partner taking over (at least some) financial responsibility. The duration of PPP projects varies between one and thirty years, with mere service and management contracts being of relatively short-term duration, while PPP designs which include the construction of an asset and which are refinanced by user fees are usually based on longer contract durations so as to ensure full cost recovery for the private partner. The commercial risk of failure is mainly borne by the public sector in (short-term) projects that do not affect the ownership of the asset (which remains with the public sector). In PPP where a direct contact between the private company and the customer/user exists (i.e. concessions and Build-Operate-Transfer/Build-Own-Operate/Build-Own-Operate-Transfer PPP variants), the private partner has to shoulder the main portion of the commercial

\footnotetext{
${ }^{1}$ This paper covers - in line with the World Bank's definition of infrastructure - telecommunications, transport, energy and water supply/sanitation infrastructures.
} 
risk, e.g. deficits in payments, because of the high upfront costs he must refinance over extended periods of time.

The expectations related to the socio-economic outcomes of PPP differ substantially among participants and stakeholders, but are usually very high among all participants compared to their assessment (or perception) of the outcomes the institutional status quo ante. The public partner focuses on its need to procure additional capital as well as to attract managerial competences and technical skills - which are of special relevance in the case of technologically complex infrastructures like water supply, sewage systems, energy, and telecommunications - without losing the political control over infrastructure provision. On the contrary, the private company the profit motive is the dominant one (Hammami et al., 2006). In addition to maximizing its profit in the specific projects at stake, the private partner typically pursues a long-term, strategic goal, tool. To gain at least indirect access, by committing to a specific PPP in a specific country, to a market which is not open for full privatisation (yet) - an investment, in turn, in a potential first mover advantage in the eventuality of a later privatisation (provided the company has gained a reputation as a dependable and fair partner in the PPP period). Moreover, the likelihood of winning future tenders for similar PPP projects in other countries will increase with the specific knowledge gained.

Additionally, with the related concepts of corporate social responsibility (CSR) and stakeholder activism becoming more and more relevant for multinational companies, in some special cases the decision to enter into a PPP project may not exclusively follow a short-term profit maximisation motive (narrowly defined). It may rather be intended as a signal of a high(er) degree of stakeholder orientation to customers, the public, the media, governments and NGOs from all countries where the company is doing business (UNIDO, 2002). In other words, under such circumstances a PPP activity may convince the public partner of the company's goodwill and may accordingly have influence on considering the company of being the government's preferred partner in future (case-by-case) decisions on upcoming PPP projects or privatisation programmes - thereby giving rise to another first mover advantage by raising potential rivals' costs of market entry.

Beyond the interests of the public and private partner, a third party, the (international) organisations engaged in development cooperation like the World Bank have a specific self-interest in boosting PPP. The emergence of new challenges in development cooperation, e.g. "nation building" in failed states like Afghanistan and Somalia, rises additional tasks, and the budgets of international development agencies are not keeping up with their steadily growing expenditures requirements. A stronger involvement of the private sector, especially in expensive and technologically complex infrastructure provision, may positively contribute to narrowing or even closing that gap and may also enhance the - so far often dubious - quality of the assistance (Moyo, 2009 and Schäferhoff et al., 2007).

The potentially pivotal role of private enterprise in promoting economic development has therefore rightly been highlighted by key institutions of development cooperation, e.g. in the United Nations' "Global Compact", which has been established to involve the private sector (Annan, 1999). Even the declaration of the United Nations' Millennium Development Goals emphasises the crucial role of private companies as stakeholders in development cooperation to achieve a substantial reduction of global poverty by 2015 .

As a consequence, more and more PPPs have emerged in developing countries, and it appears from anecdotal evidence as if the peak has not been reached yet, despite comprehensive data still lacking. But from the number of PPP in infrastructure projects which is a good proxy for overall private-sector investment in public services, we can observe an increase of both the investment volume itself and the sheer numbers in all regions worldwide since the 1990s. Also additional projects in countries which had not been covered before have been implemented in 
the last decade (World Bank PPI Data Base). ${ }^{2}$ In many developing countries, the political and public awareness of their potential merits as a toll on development strategies is rising. Political initiatives like "national strategies" and specific ministries have been established to integrate more private partners in the provision of public goods and infrastructure, and more efficiently and effectively (Smith et al., 1997).

\section{Model and results}

\section{Model and variables}

One of the main challenges in testing the impact of "good governance" or "institutional quality" in private sector involvement is not only to define what a "sound" or "good" institution" is, but also how to adequately operationalise the concept of "institutional quality" for quantitative research. Several issues have to be addressed and solved, with the conceptual difference between the material institution itself (the content dimension) and the question whether this institution is also truly enforced (or perceived to be) (the trust dimension) being of pivotal importance (Voigt, 2002).

Generally speaking, the assessment of public policy or public institutions as well as the assessments of the public administration is built on a limited selection of indicators. As for the political level, accountability and democratic structures are popular variables, while for the administrative level, effectiveness of the bureaucracy or control of corruption are often utilised. This approach in many cases may be misleading, as e.g. the selection/composition of indicators may be biased by the research design or data-availability, or the comparability of different administrations may not be given (see Van de Walle, 2006). Consequently, a number of different indicators and measurement methods are used in the respective economic, administrative or political science literature. There is a number of arguments against or in favour of using a specific indicator, depending on the goal and/or range of the respective work (see for the discussion in detail e.g. Bovaird and Löffler (2003) or Van de Walle (2006). As for our study, many of these popular indicators are either too specific, as they focus on the output or outcome of the bureaucracy, too wide (focusing on the general business environment or the political system), or do not cover the necessary range of countries which are included in our empirical assessment.

Another problem which arises in this context is the question of how to get information on the institutional quality. In many cases the quality cannot be observed directly, so sophisticated extrapolations or estimates have to be applied. Another option is measuring the perception of institutional quality among citizens, officials and companies. Using this method, the construction of the indicator relies on different peoples' evaluation of one reality, but there is no guarantee that these evaluations truly reflect reality, or are at least remotely representative. It is therefore safe to assume that there is always a bias, not least as the people who were interviewed may have an own interest in a specific outcome so that they attempt to create a systematic bias by their willfully deceptive answers. A further possibility is that the bias occurs by accident, but remains unnoticed. This is particularly true in cases where different people are asked, who are subject themselves to an unequal bias due to their deviating respective interests, their different abilities to judge and intellectual capabilities. This simple example is suitable to document the main problem in the construction of reliable indicators on

\footnotetext{
2 A PPP is "established" - according to the World Bank's definition - once the respective project has reached the stage of contractual or financial closure, irrespective of later modifications in the contract or a complete failure of the PPP
} 
institutional quality, and could be easily extended to cover a broad range of other governance indicators as well.

Additionally, even where a quantitative approach to constructing indicators can be reasonably applied, as for those indicators or their components no (substantial) measurement problems on the country level exist (e.g. regarding the number of patents), the questions remain how reliable these statistics really are and whether the pertinent national data are comparable across countries.

Another caveat results from the fact that there may be no significant difference with respect to outcomes between those cases where the institution itself is identified as "weak" and those other cases where it is just being perceived as being weak by the actors involved, like enterprises or individuals. In this case, there may be another specific kind of bias: The sheer existence of an institution may lead to the (factually erroneous) subjective judgment that institutional quality is good without interviewees taking into consideration that in reality the institutional quality is indeed bad. An example might be the inability to properly enforce the - formally existing - institution, for instance for a chronic failure to protect (intellectual) property rights where the existence of a law does not mean that violators are actually prosecuted and/or adequately punished for their infringements.

But, despite of the manifold analytical limitation outlined above, using a combination of these disaggregated indicators does, in our view, provide an acceptable - for being broad-based - approach to measure institutional quality, without losing too much information due to too much aggregation. Therefore, we hold that the set of governance indicators generated by Kaufmann et al (2008), which measure the perception of the quality of different institutions in all countries worldwide, are an appropriate tool to measure the quality of institutions for the purposes of our study. Originally we planned to use the full set of institutional variables (Voice and Accountability, Government Effectiveness, Rule of Law, Control of Corruption, Political Stability, Regulatory Quality), as provided by Kaufmann et al. Additionally, variables like population size, inflation and the gross national income (GNI) per capita per year, and regional dummies which we consider as exogenous and which we use to control for other effects have been tested for. The choice of the variables is in full conformity with our theoretical considerations above: the variable Voice and Accountability influences the involvement (financial and/or technical) of international development agencies due to political and economic conditionality, the indicators Political Stability and Government Effectiveness function as a signal for the potential private partner of how risky a commitment might become, of how high the credibility of the government and the administration is and of how efficiently the public services work. The absence of corruption or at least a strong Control of Corruption gives a signal on the presumable transaction costs, and the indicator Regulatory Quality provides information on the regulatory framework which determines (especially in naturally monopolistic infrastructures like water supply) the day-to-day operation of the PPP.

Testing the exogenous institutional variables for multicollinearity, we found coefficients near 1 for the indicators Rule of Law, Control of Corruption, Political Stability, Regulatory Quality and Government Effectiveness. Owing to the high correlation between these indicators and the probable endogeneity induced by the latter we decided to remove the indicators Rule of Law, Control of Corruption, Political Stability and Regulatory Quality because some of the determinants covered by these indicators may be assumed to be also covered by the two remaining ones. To be more precise, a high quality of public services normally means that the administration is not corrupt, rule of law is given and an overall quality of political regulation can be assumed as being given. To include both relevant institutions, the quality of the administrative institutions as well as the political institutions, we use the indicator Government Effectiveness, which proxies for the overall quality of the public administration, while Voice and Accountability proxies for the existence of a stable democracy. 
Government Effectiveness (GE): This indicator measures the "perceptions of the public services' quality, the quality of the civil service and the degree of its independence from political pressures, the quality of policy formulation and implementation, and the credibility of the government's commitment to such policies" (Kaufmann et al., 2008).

Voice and Accountability (VA): This indicator measures the "perceptions of the extent to which a country's citizens are able to participate in selecting their government, as well as freedom of expression, freedom of association, and a free media" (Kaufmann et al., 2008).

According to the theory of institutional economics, our hypothesis is that the incidence of private sector investment and PPP projects in a country may strongly depend on the quality of local institutions. Private-sector investment in public services and infrastructure or partnership regimes between the private and the public sector on the micro-level, as outlined above, comprise several different governance regimes concerning the key elements project duration, organisational structure, and "quality" of the risk-sharing and/or the control rights for the public administration. As data on the overall volume of private investment on the microlevel is hard to obtain, we use a sound and statistically valid proxy - the number of PPP projects in infrastructure projects - instead. Accordingly, we propose some regressions of the "number of PPPs" variable, considered to be endogeneous, by using the ordinary least squares (OLS) method as well as a Poisson regression model and a negative binomial regression model, respectively, as they seem to be more suitable due to the nature of the data which appear not to completely fulfil OLS requirements (Long, 1997).

Table 1: Descriptive statistics

\begin{tabular}{cccccc}
\hline & $N$ & Minimum & Maximum & Mean & Standard Deviation \\
\hline Number of PPPs & 724 & 0.00 & 686.00 & 20.35 & 55.39 \\
GNI2 & 80.00 & 11150.00 & 1553.64 & 1669.47 \\
VA1 & -2.19 & 1.21 & -.4484 & .77632 \\
GovE2 & -2.25 & 1.39 & -.4830 & .59855 \\
Bev & 71079.00 & 1311020000.00 & 40541783.31 & 149814932.48 \\
Inflation & -24.00 & 5400.00 & 29.0127 & 254.19555 \\
\hline
\end{tabular}

Using the variables discussed above, we ran a cross-sectional model with data for up to six years and for 118 countries (unbalanced panel; see the annex for the complete list of countries). The descriptive statistics can be drawn from Table 1.

\section{Results and discussion}

As can be drawn from Table 2, the results from the different models used show a high degree of consistency in terms of the sign of the respective coefficient and the significance level. Additional tests for robustness (not displayed), using different indicators for institutional quality, validate the findings of the regression models used. In all cases, the Fisher-Test (F-test) and the omnibus-test indicate that the model is significant at 1 per cent level; also the goodness of fit (for the non-OLS models Pearson's chi-squared statistic and log-likelihood, as well as $R^{2} / R^{2}$ adjusted for OLS) is high for the models displayed.

The indicator Voice and Accountability (VA) displayed a significant negative correlation with the number of PPP projects in a country, as the coefficient is negative for the OLS-regression and beyond 1 for the non-OLS regressions. This implies that a higher degree of democratic participation inhibits partnerships with private enterprise and decreases the odd that a large number of PPPs exists. This result, at first glance, seems to be inconsistent with the theoretical explanation that democratic institutions will foster the implementation of PPP. On closer inspection, however, it can be explained through the governments' willingness to use private 
sector participation. It might be the case that democratic governments would prefer full privatisation because they have no fear of a loss of political control over the affected sector. In these cases, they will not resort to PPP solutions, but will rather liberalise the complete sector and open it completely to the private sector (which might result in a mixed economy setting of public suppliers competing with private firms in the same sector). On the other hand, semi-democratic or autocratic regimes (characterised by a relatively low value for Voice and Accountability), which are not willing to hand over control of vital infrastructure sectors, prefer to use PPP projects as opposed to full-blown privatisation.

Table 2: Results of the regression analysis

\begin{tabular}{|c|c|c|c|c|}
\hline Independent variable & OLS & \multicolumn{2}{|c|}{ NegBin } & Poisson \\
\hline Intercept & $\begin{array}{c}14,427 \\
(2,967)^{\star *}\end{array}$ & $\begin{array}{c}3,502 \\
(0,055)^{\star *}\end{array}$ & $\begin{array}{c}16,624 \\
(0,0903)^{\star *}\end{array}$ & $\begin{array}{c}3,349 \\
(0,009)^{\star *}\end{array}$ \\
\hline Population & $\begin{array}{l}2,503 \mathrm{E} 7 \\
(25,551)^{* *}\end{array}$ & - & - & - \\
\hline Inflation (\%) & $\begin{array}{c}0.000 \\
(-0,079)\end{array}$ & - & - & - \\
\hline $\begin{array}{l}\text { Real GNI per Capita } \\
\text { (lagged by one Year) }\end{array}$ & $\begin{array}{c}0,007 \\
(6,229)^{\star *}\end{array}$ & - & $\begin{array}{c}1,000 \\
(3,1331 \mathrm{E}-005)^{\star *}\end{array}$ & - \\
\hline Government & 10,945 & 1,819 & 4,139 & 1,293 \\
\hline Effectiveness (index) & $(2,668)^{\star *}$ & $(0,104)^{\star *}$ & $(0,1072)^{\star \star}$ & $(0,015)^{\star *}$ \\
\hline $\begin{array}{l}\text { Voice and Accountability } \\
\text { (index) }\end{array}$ & $\begin{array}{c}-10,945 \\
(-3,916)^{\star *}\end{array}$ & $\begin{array}{c}-0,473 \\
(0,076)^{\star *}\end{array}$ & $\begin{array}{c}0,633 \\
(0,0688)^{\star *}\end{array}$ & $\begin{array}{c}-0,545 \\
(0,013)^{\star *}\end{array}$ \\
\hline $\begin{array}{c}\text { Dummy East Asia and } \\
\text { Pacific }\end{array}$ & $\begin{array}{l}-7,829 \\
(-1,466)\end{array}$ & - & - & - \\
\hline $\begin{array}{l}\text { Dummy Europe and } \\
\text { Central Asia }\end{array}$ & $\begin{array}{c}-4,300 \\
(-0,797)\end{array}$ & - & - & - \\
\hline $\begin{array}{c}\text { Dummy Sub-Sahara- } \\
\text { Africa }\end{array}$ & $\begin{array}{c}-19,983 \\
(-4,590)^{\star *}\end{array}$ & - & - & - \\
\hline Dummy MENA & $\begin{array}{c}-37,404 \\
(-6,070)^{\star *}\end{array}$ & $\begin{array}{c}-1,438 \\
(0,141)^{* *}\end{array}$ & - & $\begin{array}{c}-1,743 \\
(0,048)^{\star *}\end{array}$ \\
\hline Dummy South Asia & $(-5,474)^{* *}$ & . & - & - \\
\hline Observations & 714 & 695 & 695 & 695 \\
\hline $\mathrm{R}^{2} / \mathrm{R}^{2}$ adjusted & $0,574 / 0,567$ & & & \\
\hline
\end{tabular}

T-statistics in parentheses: ${ }^{* *}$ significant at 1 percent Sources: Author's Compilation, data sources: World Bank PPI-Date Base, Kaufmann et al 2008.

The indicator Government Effectiveness has, in all models, the expected positive sign as well as a significant impact. This result is consistent with the theoretical analysis from an institutional economics perspective. It also substantiates our assumption that the existence - or at least the perception - of a high quality of the public service and a highly credible bureaucracy foster the implementation of PPP. If the quality of the civil service and the credibility of the government's commitment is high, the odd increases that PPPs are implemented. This might be caused by the direct signalling function of Government Effectiveness to the private sector, and to the international development agencies alike, which are more likely to support PPPs if "good" governance exists.

While the overall macroeconomic development, proxied by economic wealth and the inflation rate of the respective country does not matter, the size of the country in terms of population does. Further studies should include this factor, whether by standardisation of the number of PPPs on population or through using other dependent variables as e.g. average investment volumes per capita. First empirical tests, standardizing the number of PPPs on population, nevertheless underpin the outcomes discussed above. Furthermore, there are significant differences between the regions of the World, which cannot be explained by the institutional or economic conditions tested for. These regional differences may be explained by the missing political will to include the private sector in service provision at all. Also "time-lags" may be an explanation, as some regions are lagging behind in terms of only recently opening up towards private sector participation, such that private companies may lack the will to invest in politically unstable regions like the Middle East and North Africa. 


\section{Concluding remarks}

The results of our research provide strong evidence that a significant positive relationship exists between the indicator Government Effectiveness and the number of PPP projects in a country. As PPP numbers can be used as a reliable proxy for the total involvement and investment of private enterprises in public services and infrastructure, our results can be extended to assess the overall impact of institutions on this kind of private sector involvement. Therefore, our findings stress the importance of a sound institutional framework for more private sector involvement, which is likely to lead to economic growth. Amongst other explanations, such as the lack of political will to attract private capital, a low institutional quality may therefore provide a powerful explanation for the lack of private investment in many countries. From the perspective of prospective private sector partners, weak institutions increase uncertainty and, as a some kind of "collateral damage" also the project-related transaction costs, which may thus explain the private sector's lack of will or its inability to engage in PPP projects in a specific country. This finding is even more important against the trivial insight that in particular large or international private companies are able to decide relatively independently where to invest their resources in a PPP because of the fast growing demand for private capital and expertise in public services and infrastructure worldwide.

The creation of sound and trusted institutions, especially on the micro-level, in administration, to "cure" the incompleteness of public-private contracts and to reduce transaction costs therefore is a crucial first step to attract private enterprises whose investment may substantially contribute to economic growth and development. Therewith, our work gives some hints on a "second institutional channel of development" - sound institutions do not only influence foreign direct investment in the narrow sense, but also private sector activities in the provision of public services. This seems to be important as the private enterprises included in our study come from industrialised "foreign" countries as well as from the respective country itself. Improving framework conditions for both kinds of enterprises to invest in public infrastructure may be an important instrument of the political level, but also the administration itself to foster long-term growth.

\section{References}

Acemoglu, Daron and James A. Robinson (2012) Why nations fail. New York: Crown Business.

Apolte, Thomas (2004) 'Discussion on Wagener: Buon governo - mal governo', in Thomas Eger (ed) Erfolg und Versagen von Institutionen. Berlin: Duncker \& Humblot, pp. 141-145.

Annan, Kofi (1999) 'Address at the World Economic Forum in Davos', UN Press Release SG/SM/6881. http://www.un.org/News/Press/docs/1999/19990201.sgsm6881.html (consulted 19.03.2013).

Bovaird, Tony and Elke Löffler (2003) 'Evaluating the Quality of Public Governance: Indicators, Models and Methodologies', International Review of Administrative Sciences 69(3): 313-328.

Budäus, Dietrich and Birgit Grüb (2007) 'Anhaltspunkte und Hypothesenbildung für eine Theorie der Public Private Partnership', in Dietmar Bräunig and Doeothea Greiling (eds) Stand und Perspektiven der Öffentlichen Betriebswirtschaftslehre II. Berlin: Berliner Verlagsgesellschaft, pp. 421-431.

Coase, Ronald H. (1937) 'The Nature of the Firm”, Economica, 4(16): 386-405. 
Dudkin, G. and Välilä, T. (2005) 'Transaction Costs in Public Private Partnerships: A First Look at the Evidence', European Investment Bank Economic and Financial Report 2005/03.

Erlei, Mathias, Martin Leschke and Dirk Sauerland (2007) Neue Institutionenökonomik, 2nd edition, Stuttgart: Beck.

Grimsey, Darrin and Mervyn K. Lewis (2005) 'Introduction' in Darrin Grimsey and Mervyn K. Lewis (eds) The Economics of Public Private Partnerships. Cheltenham: Edward Elger, pp. xiii-xl.

Gschlößl, Susanne and Claudia Czado (2008) 'Modelling count data with overdispersion and spatial effects', Statistical Papers 49:531-552

Hammami, Mona, Jean-François Ruhashyankiko and Etinne B. Yehoue (2006) 'Determinants of Public Private Partnerships in Infrastructure', IMF Working Paper WP/06/99.

Hartwig, Karl-Hans (2005) 'Infrastrukturpolitik in der Diskussion', in Karl-Hans Hartwig and Andreas Knorr (eds) Neuere Entwicklungen in der Infrastrukturpolitik. Beiträge aus dem Institut für Verkehrswissenschaften an der Universität Münster. Heft 157. Göttingen, pp. 8-30.

Hart, Oliver (2005) 'Incomplete Contracts and Public Ownership: Remarks, and an Application to Public-Private Partnerships', in Darrin Grimsey and Mervyn K. Lewis (eds) The Economics of Public Private Partnerships, Cheltenham: Edward Elgar, pp. 295-314.

Hodgson, Geoffrey M. (1998) 'The Approach of Institutional Economics', Journal of Economic Literature 36(1): 166-192.

Kaufmann, Daniel, Aart Kraay and Massimo Mastruzzi (2008) Governance Matters VIII: Worldwide Governance Indicators 1996-2008', Policy Research Working Paper 4654, World Bank Development Research Group.

Klein, Michael, Jae So and Ben Shin (1996) 'Transaction Costs in Private Infrastructure: Are They Too High?', Worldbank Private Sector Development Department Viewpoint Note No. 95.

Klein, Peter and Hung Luu (2003) 'Politics and Productivity', Economic Inquiry 41(3): 433-447.

Linder, Stephen H. (1999) 'Coming to Terms with the Public-Private Partnership: A Grammar of Multiple Meanings', American Behavioral Scientist 43(1): 35-51.

Long, Scott J. (1997) Regression Models for Categorical and Limited Dependent Variables (Advanced Quantitative Techniques in the Social Sciences), Thousand Oaks: Sage.

Moyo, Dambisa (2009) Dead Aid. Why Aid Is Not Working and How There Is a Better Way for Africa, New York: Farrar, Straus and Giroux.

North, Douglass C. (1991) 'Institutions', Journal of Economic Perspectives, 5(1): 97-112.

North, Douglass C. (1992) Institutionen, institutioneller Wandel und Wirtschaftsleistung, Tübingen: Mohr Siebeck.

Nuscheler, Franz (2005) Entwicklungspolitik, 5th edition. Bonn: BpB

Obinger, Herbert (2001) 'Demokratie, Institutionen und ökonomische Entwicklung: eine Replik auf Christian Martin und Thomas Plümper', Swiss Political Science Review 7(3): 81-96.

Organisation for Economic Co-Operation and Development (OECD) (2007) Statistical Annex of the 2007 Development Cooperation Report, Paris,http://www.oecd.org/ dataoecd/52/9/1893143.xls (consulted 13/12/2013) 
Parker, David and Keith Hartley (2005) 'Transaction costs, relational contracting and public private partnerships: a case study of UK defence' in Darrin Grimsey and Mervyn K. Lewis (eds) The Economics of Public Private Partnerships, Cheltenham and Northampton: Edward Elgar, pp. 303-314.

Richter, Rudolf and Eirik. G. Furubotn (1999) Neue Institutionenökonomik, 2nd edition, Tübingen: Mohr Siebeck.

Sachs, Jeffrey D. and Andrew M. Warner (1997) 'Natural Resource Abundance and Economic Growth', Center for International Development and Harvard Institute for International Development Discussion Paper, NBER Working Paper 5398.

Schäferhoff, Marco, Sabine Campe and Christopher Kaan (2007) 'Transnational Public-Private Partnerships in International Relations: Making Sense of Concepts, Research Frameworks and Results', SFB-Governance Working Paper Series 6.

Smith, Graham R., N. Shafik, P. Guislain and J. A. Reichert (1997) Getting Connected: Private Participation in Infrastructure in the Middle East and North Africa, World Bank Middle East and North Africa Economic Studies, Washington D.C.: World Bank.

United Nations Industrial Development Organization (UNIDO) (2002) UNIDO Business Partnerships for Industrial Development, Vienna.

Van de Walle, Steven (2006) 'The State of the World's Bureaucracies', Journal of Comparative Policy Analysis 8 (4): 437-448.

Voigt, Stefan (2002) Institutionenökonomik, Paderborn: Fink.

Wagener, Hans-Jürgen (2004) 'Die Bedeutung guter Regierung für Wohlfahrt und Transformation', in Thomas Eger (ed.) Erfolg und Versagen von Institutionen, Berlin: Duncker \& Humblot, pp. 119-140.

Williamson, Oliver E. (1975) Markets and Hierarchies: Analysis and Antitrust Implications. A Study in the Economics of Internal Organization. New York: Free Press.

Williamson, Oliver E. (1985) The Economic Institutions of Capitalism, Cambridge: Cambridge University Press.

Williamson, Oliver E. (2000) 'The New Institutional Economics: Taking Stock, Looking Ahead', Journal of Economic Literature 38(3): 595-613.

World Bank PPI Data Base (ongoing) Private Participation in Infrastructure Database, http://ppi.worldbank.org (consulted 26/12/2013).

Ziekow, Jan (2003) 'Verankerung verwaltungsverfahrensrechtlicher Kooperationsverhältnisse', in Jan Ziekow (ed) Public Private Partnership Projekte, Probleme, Perspektiven, Speyer: Speyer University, pp. 25-78. 


\section{Annex}

Table A1: Countries included in the empirical Analysis

\begin{tabular}{|c|c|c|c|}
\hline Albania & Cuba & Laos & Somalia \\
\hline Algeria & Djibouti & Lesotho & South Africa \\
\hline Albania & Dominica & Liberia & Sri Lanka \\
\hline Angola & Dominican Republic & Madagascar & Sudan \\
\hline Argentina & East Timor & Malawi & Surinam \\
\hline Armenia & Ecuador & Malaysia & Swaziland \\
\hline Azerbaijan & Egypt, Arab Rep. & Maldives & Syria \\
\hline Bangladesh & El Salvador & Mali & Tadzhikistan \\
\hline Belarus & Eq. Guinea & Mauretania & Tanzania \\
\hline Belize & Eritrea & Mauritius & Senegal \\
\hline Benin & $\mathrm{Fiji}$ & Mexico & Seychelles \\
\hline Bhutan & Gabon & Moldavia & Sierra Leone \\
\hline Bolivia & Gambia & Mongolia & Thailand \\
\hline Botswana & Georgia & Morocco & Togo \\
\hline Brazil & Ghana & Mozambique & Tonga \\
\hline Burkina Faso & Grenada & Namibia & Tunisia \\
\hline Burundi & Guatemala & Nepal & Turkey \\
\hline Cambodia & Guinea & Nicaragua & Turkmenistan \\
\hline Cameroon & Guyana & Niger & Uganda \\
\hline Cape Verde & Haiti & Nigeria & Ukraine \\
\hline Central African Republic & Honduras & Oman & Uruguay \\
\hline Chad & India & Pakistan & Uzbekistan \\
\hline Chile & Indonesia & Panama & Vanuatu \\
\hline China & Iran, Islam. Rep. & Papua New Guinea & Venezuela \\
\hline Colombia & Ivory Coast & Paraguay & Vietnam \\
\hline Comoros & Jamaica & Peru & West Bank and Gaza \\
\hline Congo & Jordan & Philippines & Yemen \\
\hline Congo, Dem. & Kazakhstan & Poland & Zambia \\
\hline Costa Rica & Kenia & Russian Federation & \\
\hline Colombia & Kiribati & Ruanda & \\
\hline Comoros & Kirgizstan & Samoa & \\
\hline
\end{tabular}

